\title{
高精細映像再生に向けたホログラムメモリー信号処理アルゴリズム
}

\section{Readout Signal Processing Algorithm for Holographic Memory toward High Definition Video} Playback

\author{
正会員 木下延博 ${ }^{\dagger}$, 正会員 室井哲颜 ${ }^{\dagger}$, 正会員 石 井紀 彦 ${ }^{\dagger}$, \\ 正会員上條晃司 ${ }^{\dagger}$, 正会員菊池宏 ${ }^{\dagger}$, 正会員清水直樹 ${ }^{\dagger}$ \\ Nobuhiro Kinoshita ${ }^{\dagger}$, Tetsuhiko Muroi ${ }^{\dagger}$, Norihiko Ishii ${ }^{\dagger}$, \\ $\mathrm{Koji} \mathrm{Kamijo}^{\dagger}$, Hiroshi Kikuchi ${ }^{\dagger}$ and Naoki Shimidzu ${ }^{\dagger}$
}

あらまし ホログラムメモリーは，ページデータと呼ばれる2次元データ配列を一括して記録または再生する光情 報記録システムである。ページデータの重畳された再生光はイメージセンサで撮影され，デー夕領域特定，シンボル 抽出，デインタリーブ，䛊り訂正の順に信号処理することで元のデータを復元できる. 撮影された再生像は一種の画 像であることに着目し，画像処理に特化したGPU (Graphics Processing Unit)によるホログラムメモリーの再生信号 処理アルゴリズムを新規に開発した。各処理段をパイプライン化することにより，GPUによる再生信号処理系として $95 \mathrm{Mbps}$ 以上のスループットを確認した．次いで，高精細映像をホログラムとして記録再生した結果，すべてのビッ ト誤りが訂正され，映像再生されることを確認した。

キーワード：光メモリー, ページデータ，ブロックマッチング，シンボル抽出，デインタリーブ，誤り訂正

\section{1.まえがき}

ホログラムメモリー1) 4) は光の干渉を利用した情報記録 システムである，光源としてレーザ光を用い，情報記録時 には参照光と, データを重畳した信号光とを記録媒体へ同 時に照射して干渉させ, これを屈折率差や吸光度差として 記録媒体に記録したものがホログラムである. 情報再生時 には参照光のみを記録媒体へ照射し，ホログラムにより生 じる回折光を検出後, 元デー夕を復号する. 記録媒体への 参照光の入射角度を変化させながら, 記録媒体の同一箇所 に複数のホログラムを重ね書き(角度多重) できるため大容 量化が可能である ${ }^{5)}$.. また， $1 \mathrm{Mb}$ 程度の情報量をもつ 2 次元配列ディジタルデータ (ページデータ)を一度の光照射 で一括して記録または再生できるため, 高転送レート化に 有利である。このような特徴を有するホログラムメモリー は，高精細映像記録システムとしてその実用化が期待され ている.さらに, 光強度に応じてモノマを重合させる感光 性有機材料 7) を記録材料として用いた場合, 記録後の長期 保存性が優れていることから映像アーカイブス用途にも適 している.

すでに広く普及した光メモリーであるCD (Compact Disc)

2012年12月 13 日，マルチメディアストレージ研究会で発表

2014年1月 30 日受付，2014年5月 19 日採録

$\dagger$ NHK 放送技術研究所

（₹ 157-8510 世田谷区砧 1-10-11，TEL 03-5494-3276)
やDVD (Digital Versatile Disc), BD (Blu-ray Disc) が記録層 のマークの有無を記録または再生する Bit-wise型であるの に対し，ホログラムメモリーはページデータを扱う Pagewise型であるため, その再生信号処理手法が従来の光メモ リーとは大きく異なる。ホログラムからの再生光はイメー ジセンサで撮影され, その再生像にページデータが含まれ ている.この場合, 画像処理の性質を持つ再生信号処理が 必要となる。

ところで近年，コンピュータのグラフィクス処理に特化 したデバイスである GPU (Graphics Processing Unit)を画 像処理や映像処理, 汎用計算に用いる試みが多方面で行わ れている8) 11). GPUは数 100 もの演算コアを有し, 高い 並列演算数による高速演算が可能であるとともに，信号処 理アルゴリズム構成やパラメータをその都度プログラミン グにより容易に変更できるという特徴を持つ ${ }^{12)}$.

一方，ホログラムメモリーにおいて，ページデータを含 む再生像を一種の画像であると見なせば，グラフィクス処 理に特化したGPUがホログラムメモリーの再生信号処理回 路として有効に機能するものと考えられる. しかしながら, GPUの特性を活かしたホログラムメモリーの再生信号処理 アルゴリズムについて，これまで充分な有効性の検証・評 価が為されたとは言えない.

そこで今回，GPUによるホログラムメモリーの再生信号 処理アルゴリズムを新規に開発した。本論文では，第 2 章 でホログラムメモリーの光学系, ページデータ構成, 再生 
信号処理系を概説し，第3章で各再生信号処理段のアルゴ リズムを詳述する。第4章ではGPUによる各処理段の時間 測定結果を示した後, 高精細映像の再生実験によりGPU再 生信号処理アルゴリズムを総合的に評価し，その有効性を 検証する。

\section{2. ホログラムメモリーの構成}

\section{1 光学系}

図1にホログラムメモリーの記録再生光学系を示す。波 長 $532 \mathrm{~nm}$ のレーザビームをスペイシャルフィルタにより 空間ノイズ除去後に径拡大し, 半波長板 (Half-Wave Plate: HWP) 1 と偏光ビームスプリッタ (Polarizing Beam Splitter: PBS) 1により信号光と参照光に分離する. 信号光 は空間光変調器 (Spatial Light Modulator: SLM) 上に表示 されたページデータで空間的に変調され，フーリエ変換レ ンズ (Fourier Transform Lens: FTL)により一度集光され る. SLM として画素ピッチ $10.4 \mu \mathrm{m}$, 画素数 $1,400 \times 1,050$ の反射型液晶パネルを用いた. FTLを出た信号光の集光点 に矩形開口A1 を配置することで高次の空間高周波成分を 除去し, リレーレンズ (Relay Lens: RL) 1を通過して記録 媒体へ照射する。ここで, 矩形開口 A 1 の大きさをナイキ スト周波数の 2 倍に相当するよう定めた.

記録媒体には, 厚さ $1.2 \mathrm{~mm}$ のガラス板 2 枚に光重合性高 分子が挟まれたものを用いた ${ }^{7)}$. 記録層の厚さは $1.0 \mathrm{~mm}$ で ある。

参照光を記録時にRL2 側から，再生時にRL3 側から記録 媒体へ照射する. 記録時と逆方向から参照光を入射する再 生方法を位相共役再生 ${ }^{2)}$ と呼び, 再生光は記録時の信号光 と逆方向に伝搬し, 光学収差を相殺する作用がある。これ により収差の少ない再生像がイメージセンサへ到達する. イメージセンサとして画素ピッチ $8.0 \mu \mathrm{m}$, 画素数 $1,696 \times$ 1,710のCMOSセンサを用いた。取得画像はCameraLink イ ンタフェース (10 tap, Full Configuration)を経由して再生 信号処理系へ送られる.

\section{2 ページデータ構成}

記録すべきディジタルデータ列をページデータとして生 成する前に, 誤り訂正符号による符号化とインタリーブ処 理を施す (図2). 以下に誤り訂正符号化とインタリーブに ついて順に述べる.

今回, 誤り訂正符号として符号長 1,250 , 符号化率 0.812 の LDPC (Low Density Parity Check) 符号を用いた. LDPC 符号は, 誤り訂正能力が高い符号化方式として利用 されており，ホログラムメモリーにおいてもリードーソロ モン符号より優れていることが示されている13).

以下に情報ビット列 $\mathbf{w}$ に対する符号化手順を示す．符号 化で用いる検査行列 $\mathbf{H}$ は Gallagerの構成法を用いて生成す る.ここでは, 検査行列 $\mathbf{H} の$ 後半部分を検査ビット関連行 列 $\mathbf{P}$ とし,
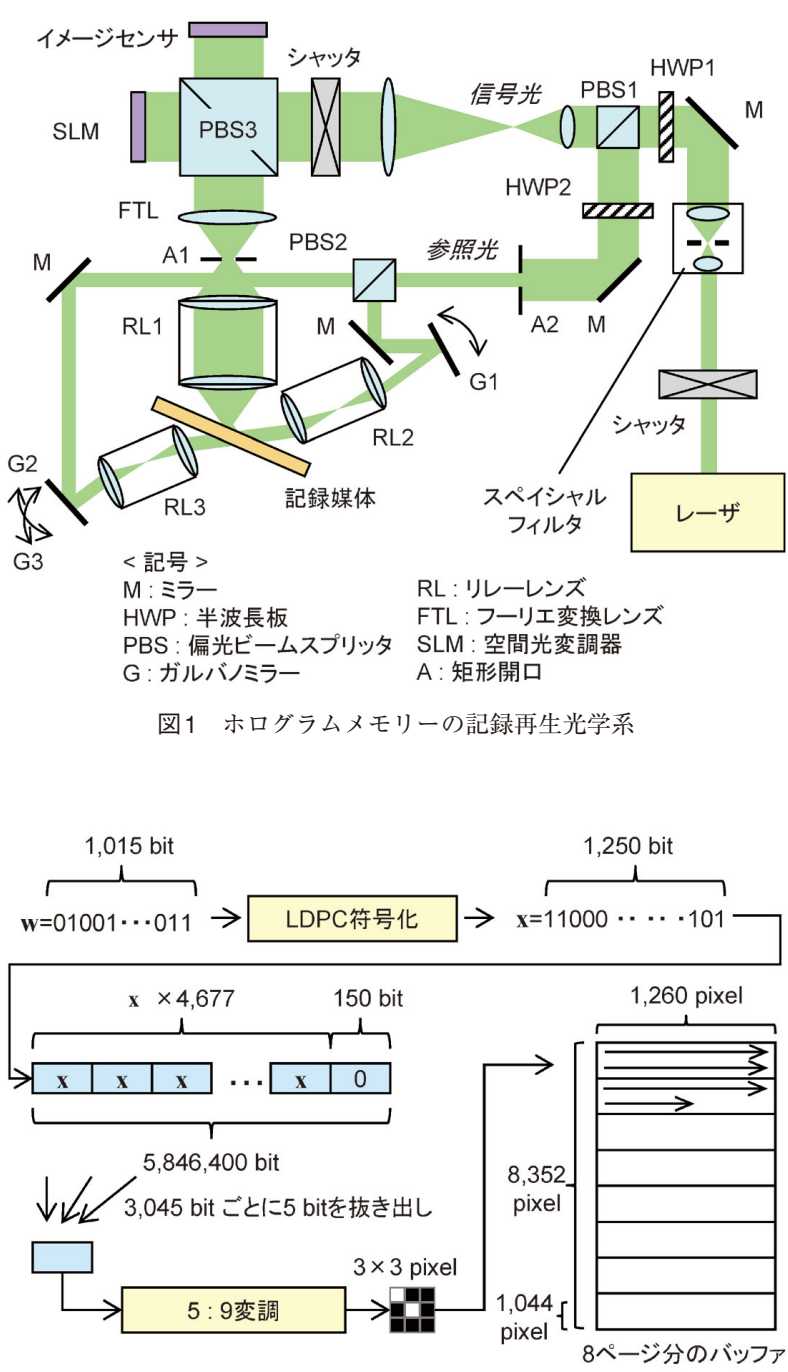

図2 誤り訂正符号による符号化とインタリーブ処理

$$
\mathbf{H}=[\mathbf{I} \mid \mathbf{P}]
$$

として構成した。ただし，Iは単位行列である。また，符 号語 $\mathbf{x}$ は，情報ビット列 $\mathbf{w}$ と圥長ビット列 $\mathbf{z} よ り ，$

$$
\mathbf{x}=[\mathbf{z} \mid \mathbf{w}]
$$

で表される．符号語 $\mathbf{x}$ と検査行列 $\mathbf{H}$ の関係は

$$
\mathbf{x} \cdot \mathbf{H}^{\mathrm{T}}=\mathbf{o}
$$

である。ここでoは零べクトル， Tは転置を示す。した がって,

$$
\mathbf{z} \cdot \mathbf{I}^{\mathrm{T}}+\mathbf{w} \cdot \mathbf{P}^{\mathrm{T}}=\mathbf{o}
$$

となり，圥長ビット列 $\mathbf{z} は$

$$
\mathbf{z}=\mathbf{w} \cdot \mathbf{P}^{\mathrm{T}}
$$

で求められる.

ページデータの一部が欠落して再生されるなど，ビット 誤りが一つの符号に集中した場合，その符号の誤り訂正が 困難になる。ビット誤りが集中しないように分散させて擬 


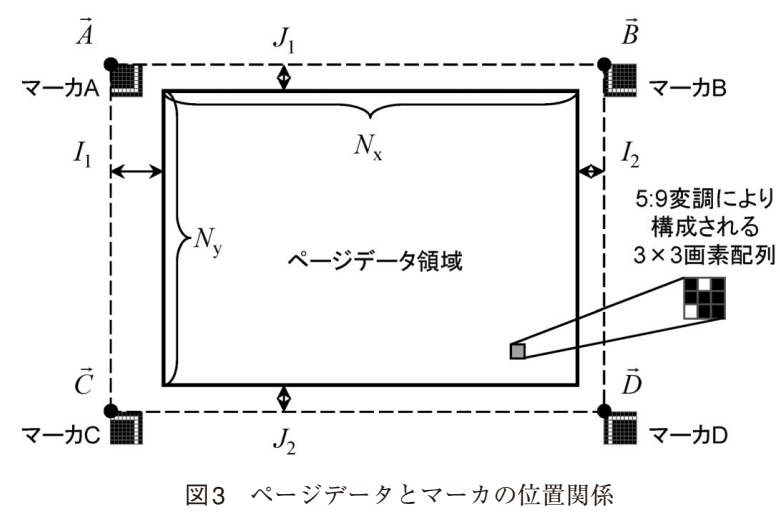

似ランダム誤りとするためにはインタリーブが有効であ る.まず，LDPC符号化により求められた符号語 $\mathbf{x} 4,677$ 個並べた後, その末尾に 150 個の 0 を付加することで長さ 5,846,400 bitの1次元配列を作成する. インタリーブ処理で は, 1 次元配列の読出し番地を 3,045 bitずつ加算しながら 順に 5 bitずつ抜き出す。ただし, 読出し番地が一周した場 合には 5 bit分の番地加算を行い, 抜き出しを継続する.

ページデータはシンボル (明点または暗点)を2次元状に 並べた画像であり，1シンボルをSLM上の 1 画素で表現す る.インタリーブ操作に基づき, 1次元配列から抜き出し た 5 bit $3 \times 3$ シンボルに対応づける $5 ： 9$ 変調 ${ }^{14)}$ を用いて 8ページデータ分のバッファヘ順次格納する.一つのペー ジデータにおける横と縦のシンボル数 $N_{x}, N_{y}$ を 1,260 と 1,044 に定めたため, 8ページバッファの横と縦の大きさは $1,260 \times 8,352$ となる. これにより, 長さ $5,846,400$ の 1 次元 配列から8枚のページデータを得る。

イメージセンサで取得される再生像内のページデータ は，一般に位置ずれや回転などの歪みを伴う。これらを補 正し, 各シンボルの位置を精度よく算出するために, マー カと呼ばれる微小画像 ${ }^{15)}$ をページデー夕領域外の 4 箇所に 配置した. 再生像内のマーカ位置を特定できれば，すべて のシンボル位置を求めることができる. 図3にページデー タとマーカの位置関係を図示する。今回はマーカ眓形とし て二つの線分が一つの交点で交わる大きさ $8 \times 8$ pixelの $\mathrm{L}$ 字状図形を用いる ${ }^{16)}$. なお図 3 中, $I_{1}, I_{2}, J_{1}, J_{2}$ はページ データからマーカへのオフセット位置を示す.

\section{3 再生信号の処理系}

従来の光ディスクと異なり, ホログラムメモリーでは画 像処理の性質を持つ信号処理が必要となる. 今回構築した 再生信号処理の流れを図4に示す。イメージセンサで取得 した再生像のうち, 像内のマーカ位置を検出しデー夕領域 を特定する. マーカ位置情報に基づきすべてのシンボルを 抽出後, デインタリーブと誤り訂正により元データを復元 する.

図 4 に示した再生信号処理段を, 図 5 のように二つの GPUに割当てた.二元のGPUはそれぞれ, 処理負荷の比 較的大きな誤り訂正と, それ以外の処理とを担う。 CPU (Central Processing Unit) はイメージセンサからの画像取

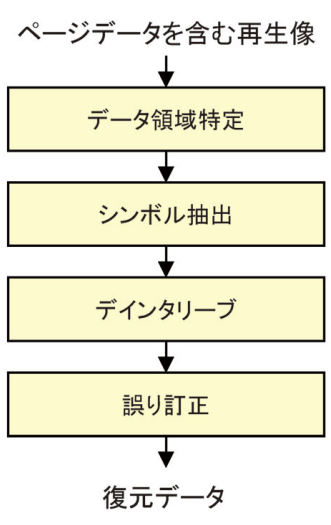

図4 再生信号処理の流れ

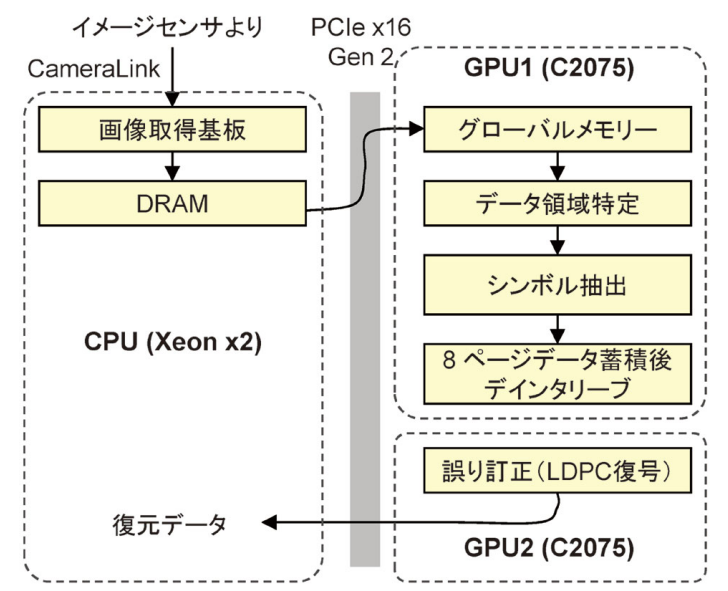

図5 GPUへの再生信号処理段の割当て

得とDRAM (Dynamic Random Access Memory) 内バッ ファへの蓄積のほか, 各処理段の同期制御を行う. CPUと してIntel Xeon X5650 (コア数6, クロック $2.66 \mathrm{GHz}$ ), GPUとしてNVIDIA Tesla C2075 (コア数448, クロック $1.15 \mathrm{GHz}$ )を用いた。 GPUは計算器内部でバス（PCI Express $\times 16$ Gen 2) に接続されている.

GPUは多数の数值演算コアを有しており，画像などの 2 次元配列を各コアに分担させ，同時に並列動作することで 高速処理できる. 処理系のプログラミングには C 言語と親 和性のあるコンパイラ, ライブラリーが提供されており ${ }^{12)}$, 処理アルゴリズム開発においてその構成やパラメータの変 更が容易である.

GPU内部では“スレッド”と呼ばれる演算コアごとの処 理単位が複数集まり, “ブロック”と呼ばれる並列処理単位 を構成する. スレッド，ブロックは $1 \sim 3$ 次元の論理的な 処理配列として定義される. GPU内のメモリーは階層構造 であり ${ }^{8)}$, 小規模データのランダムアクセスが高速な“共 有メモリー”と呼ばれる上層メモリーと, 大容量でバース 卜転送に有利な“グローバルメモリー”と呼ばれる下層メモ リーをユーザ側で指定して利用できる。この他にキャッ シュメモリーやレジスタがGPUに搭載されているが，これ らをユーザ側で明示的に制御することは困難である。実際 
のアルゴリズム構築では, 共有メモリーは高速であるが数 10 KByte程度の容量しかないこと, グローバルメモリーは 断片的なアクセスのレイテンシが速度低下を招くことに留 意し，処理すべきデータを上述の GPUブロックやスレッド に割当てることが肝要である.

GPUを用いた各処理段の具体的動作に関し, 次章で詳細 に述べる。

\section{3. 各再生信号処理アルゴリズムとGPUへの実装}

\section{1 データ領域特定}

記録時に埋め込まれたマーカ画像位置をブロックマッチン グにより探索する. マーカ画像とテンプレートには, 図3で 示したL字形状の図形を用いた. ブロックマッチングとして SSD (Sum of Squared Difference) 法を用い, パラボラ フィッティングによりサブピクセル精度で位置検出する.

SSD 法は，テンプレートを1画素分ずつラスタスキャン させながら, 再生画像との画素值の差の二乗総和が最小と なるよう探索する方法であり, 以下の評価式 $f(s, t)$ が最小 となる位置 $\left(s_{0}, t_{0}\right)$ を求める.

$$
f(s, t)=\sum_{m_{x}=1}^{M_{x}} \sum_{m_{y}=1}^{M_{y}}\left(T\left(m_{x}, m_{y}\right)-Q\left(m_{x}+s, m_{y}+t\right)\right)^{2}
$$

ここで, $M_{x}, M_{y}$ は横方向と縦方向のテンプレートの大きさ, $T\left(m_{x}, m_{y}\right)$ はテンプレート配列 $T$ の要素, $Q(x, y)$ は再生 画像を格納した配列 $Q$ の要素, $(s, t)$ は探索位置をあらわ す.ここでは $T$ を多值テンプレート ${ }^{17)}$ で構成し， $M_{x}, M_{y}$ と も 16 とした．また， $s, t$ の探索範囲をともに 8 pixel とした.

$\mathrm{SSD}$ 法により得られる位置 $\left(s_{0}, t_{0}\right)$ は整数座標であるが, 次の式で示すパラボラフィッティングによりサブピクセル 精度でマーカ位置 $\left(s_{o p t}, t_{o p t}\right)$ を算出する.

$$
\begin{aligned}
& s_{o p t}=s_{0}+\frac{1}{2} \frac{f\left(s_{0}+1, t_{0}\right)-f\left(s_{0}-1, t_{0}\right)}{f\left(s_{0}-1, t_{0}\right)-2 f\left(s_{0}, t_{0}\right)+f\left(s_{0}+1, t_{0}\right)} \\
& t_{\text {opt }}=t_{0}+\frac{1}{2} \frac{f\left(s_{0}, t_{0}+1\right)-f\left(s_{0}, t_{0}-1\right)}{f\left(s_{0}, t_{0}-1\right)-2 f\left(s_{0}, t_{0}\right)+f\left(s_{0}, t_{0}+1\right)}
\end{aligned}
$$

デー夕領域特定において最も基本的な並列化手段は，4 つのマーカ位置探索をGPUの 4 ブロックに割り振ることで ある，そのうえで，式 (6) における異なる $s$ と $t$ をブロック 内の各スレッドに対応させ, 探索範囲内での評価式 $f$ を並 列計算させる.

図3のとおりマーカ位置をあらかじめ定義しているため, 必ずしも再生像全体を探索する必要はない. GPUのグロー バルメモリーに格納された再生像のうちマーカ位置近傍の みを共有メモリーへ転送し, 同じく共有メモリーに格納し たテンプレートを用いて式 (6) を計算することが高速と考 えられる. 全スレッドが評価式 $f$ の計算を終了した後, 評 価式 $f$ 最小值探索と式 (7), 式 (8) によるパラボラフィッ ティングにより 4 つのマーカ位置ベクトル $\vec{A}, \vec{B}, \vec{C}, \vec{D}$ を

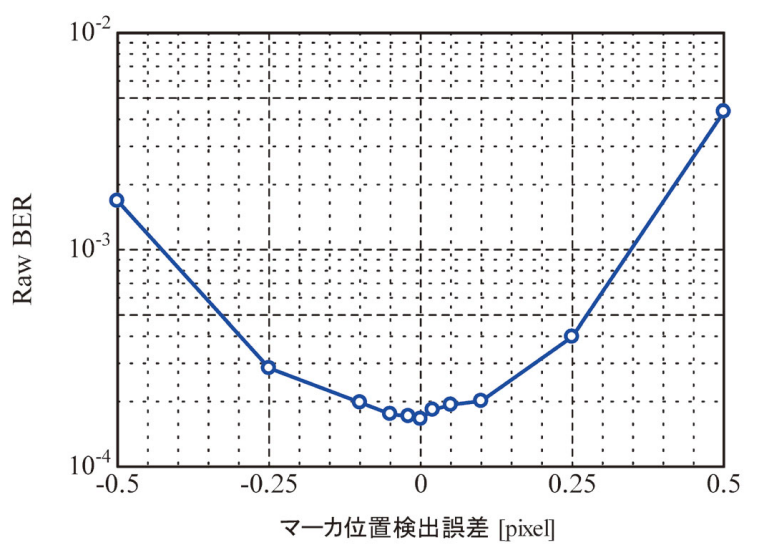

図6 マーカ位置検出誤差に対するRaw BERの変化
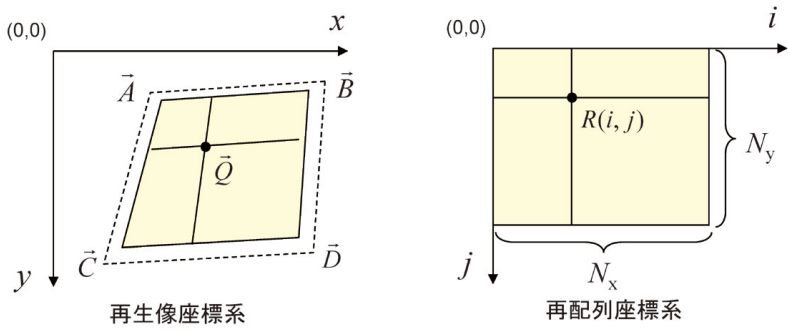

図7 再生像から再配列ページデータヘのシンボル抽出

決定する.

ここでマーカ位置検出に必要な精度を検証するため, マーカ位置 $\vec{B}$ の $x$ 方向座標に位置検出誤差を恣意的に与え た場合について，誤り訂正前のビット誤り率 (Raw BER) の変化を調べた (図6). 対象とする再生像は, 1枚のペー ジデータのみを記録媒体にホログラム記録して得た。また, シンボル抽出の条件は, 次節で述べるうちの最良な条件を 用いた. 図6の結果から，一つのマーカが 0.5 pixelの位置 誤差を生じれば1桁程度のビット誤り増加を引き起こすこ と，低いビット誤り率を維持するためには 0.1 pixel以下の 位置検出精度を要することがわかる.

\section{2 シンボル抽出}

イメージセンサで取得した再生像に含まれるページデー 夕は, 記録媒体と光学系とのミスアライメントなどにより 位置ずれや回転を含む変形された形状となるが，検出され たマーカ位置に基づく座標変換によりシンボル位置補正が できる。

図7に示すとおり，前節で求めたマーカ位置ベクトル $\vec{A}$, $\vec{B}, \vec{C}, \vec{D}$ を用いて, シンボル抽出後の再配列ページデータ 配列 $\mathbf{R}$ の要素 $R(i, j)$ に対応する再生像内のシンボル位置 ベクトル $\vec{Q}$ を次式により求める.

$$
\vec{Q}=\frac{\vec{Z}}{N_{x a} \cdot N_{y a}}
$$

ただし， 


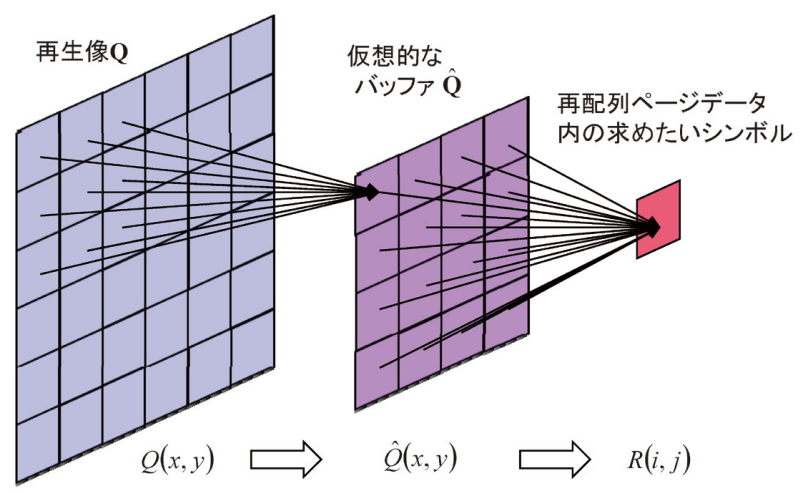

図8補間とフィルタの同時実装の概念図

$$
\begin{aligned}
\vec{Z} & \equiv\left(N_{x a}-\tilde{i}\right)\left(N_{y a}-1+J_{2}-\tilde{j}\right) \vec{A} \\
& +\tilde{i}\left(N_{y a}-\tilde{j}\right) \vec{B}+\left(N_{y a}-i\right) \tilde{j} \vec{C}+\tilde{i} j \vec{D}
\end{aligned}
$$

であり $N_{x a} \equiv N_{x}+I_{1}+I_{2}+1, N_{y a} \equiv N_{y}+J_{1}+J_{2}+1, \tilde{i} \equiv i+I_{1}$, $\tilde{j} \equiv j+J_{1}$ と定義した. 変数 $i, j$ は $0 \leq i<N_{x}, 0 \leq j<N_{y}$ の範囲 をとり, $R(i, j)$ の座標を表す.

ところで, 式 (9) で求めた位置べクトルの座標 $\vec{Q}$ は必ず しも整数にならず, シンボル抽出には補間処理が必要とな る. 一般的な画像処理手法における補間方法には, 最近傍 法(Nearest neighbor)や双1次補間(Bi-linear interpolation), 双3次補間 (Bi-cubic interpolation) などがあり，ホログラ ムメモリーにおいてもこれら補間方法が有効に機能すると 考えられる. 一方，レンズなどの光学系を通過することに より高空間周波数成分が低下しているため，これを補償す るフィルタ処理も必要である.

そこで今回, 補間機能とフィル夕機能を同時に実装した シンボル抽出法を開発した。補間とフィルタの同時実装の 概念図を図 8 に示す。再配列ページデータ上の任意の点 $R$ $(i, j)$ を再生像上の点 $Q(x, y)$ から求める際, 仮想的なバッ ファ配列 $\hat{\mathbf{Q}}$ を経由させる.

再生像 $\mathbf{Q}$ から仮想バッファ $\hat{\mathbf{Q}}$ の遷移において, フィル 夕処理として次式で与えられるコンボリューションフィル タを実装した。

$$
\hat{Q}(x, y)=\sum_{X=1}^{3} \sum_{Y=1}^{3} c(X, Y) \cdot Q(x+X-2, y+Y-2)
$$

ただし, $c(X, Y)$ は次の係数行列 $\mathbf{C}$ の要素を表す.

$$
\mathbf{C}=\left(\begin{array}{ccc}
C_{2} & C_{1} & C_{2} \\
C_{1} & 1 & C_{1} \\
C_{2} & C_{1} & C_{2}
\end{array}\right)
$$

ここで, $C_{1}, C_{2}$ はフィルタ係数である. 次に仮想バッファ $\hat{\mathbf{Q}}$ の要素 $\hat{Q}(x, y)$ からシンボル值 $R(i, j)$ を抽出する際に 用いる補間は，演算子 [] 皇数点以下切捨てとし次のよ うに与えた。
$<$ 最近傍法 $>$

$$
R(i, j)=\hat{Q}([x+0.5],[y+0.5])
$$

$<$ 双 1 次補間 $>$

$$
R(i, j)=\sum_{X=[x]}^{[x]+1} \sum_{Y=[y]}^{[y]+1} \hat{Q}(X, Y) h(X-x) h(Y-y)
$$

ただし，

$$
h(t)=\left\{\begin{array}{cc}
1-|t| & (0 \leq|t|<1) \\
0 & (1 \leq|t|)
\end{array}\right.
$$

$<$ 双3次補間 $>$

$$
R(i, j)=\sum_{X=[x]-1}^{[x]+2} \sum_{Y=[y]-1}^{[y]+2} \hat{Q}(X, Y) h(X-x) h(Y-y)
$$

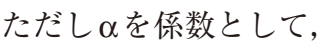

$$
h(t)=\left\{\begin{array}{cc}
(\alpha+2)|t|^{3}-(\alpha+3)|t|^{2}+1 & (0 \leq|t|<1) \\
\alpha|t|^{3}-5 \alpha|t|^{2}+8 \alpha|t|-4 \alpha & (1 \leq|t|<2) \\
0 & (2 \leq|t|)
\end{array}\right.
$$

GPUへの実装においては，一つのスレッドが1シンボル $R(i, j)$ のフィルタ処理と補間処理を担うこととした. ペー ジデー夕全体を複数のブロックに分け，それらを並行して 処理させる．隣接シンボルを担当するスレッドが互いに同 一の再生像画素を参照することから，グローバルメモリー に格納された再生像のうち参照すべき画素の集合を共有メ モリーに格納することで, メモリーアクセスの高速化を図 る.すなわち, 図8の再生像 $\mathbf{Q}$ と仮想的なバッファ $\hat{\mathbf{Q}}$ の一 部を共有メモリー内に存在させる。再配列ページデータ R の横, 縦の大きさ $N_{x}, N_{y}$ はそれぞれ 1,260 と 1,044 であるか ら, ブロック数 $40 \times 33,1$ ブロックあたりのスレッド数 $32 \times 32$ とした.

次に, 記録媒体に1枚のページデータをホログラム記録 して得られた再生像を用いて，上述した補間とコンボ リューションフィルタの同時実装効果を検証する. 式 (12) のコンボリューションフィルタ係数 $C_{2}=0$ とし, $C_{1}$ を変化 させた場合の Raw BERを図9に示す。なお, 双3次補間に ついては式 (17) の係数 $\alpha=-0.6$ とした. 図9の結果から, 補間方法により特性が大きく異なり, 最良な $C_{1}$ の值も異な ることがわかる。

各補間方法におけるコンボリューションフィルタ係数 $C_{1}$ を最良な值 (最近傍法, 双 1 次補間, 双 3 次補間についてそ れぞれ $\left.C_{1}=-0.225,-0.26,-0.235\right)$ に固定したうえで $C_{2}$ を変化させた場合の Raw BERを図10に示す。なお，双 3 次補間については式 (17) の係数 $\alpha=-0.6$ とした。どの補 間方法においても $C_{2}=0.01$ で最良の誤り率を得た.

双 3 次補間について, コンボリューションフィルタ係数 


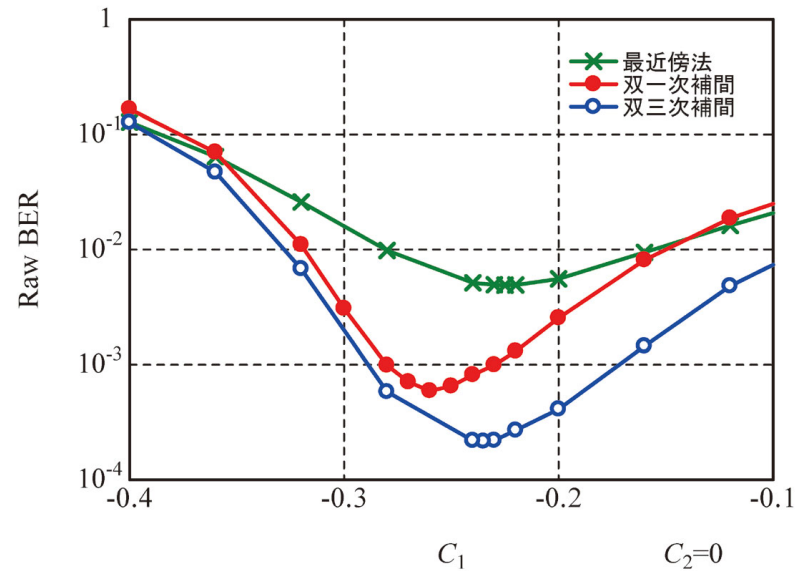

図9 各補間方法での $C_{1}$ に対するビット誤り率の変化 $\left(C_{2}=0, \alpha=-0.6\right)$

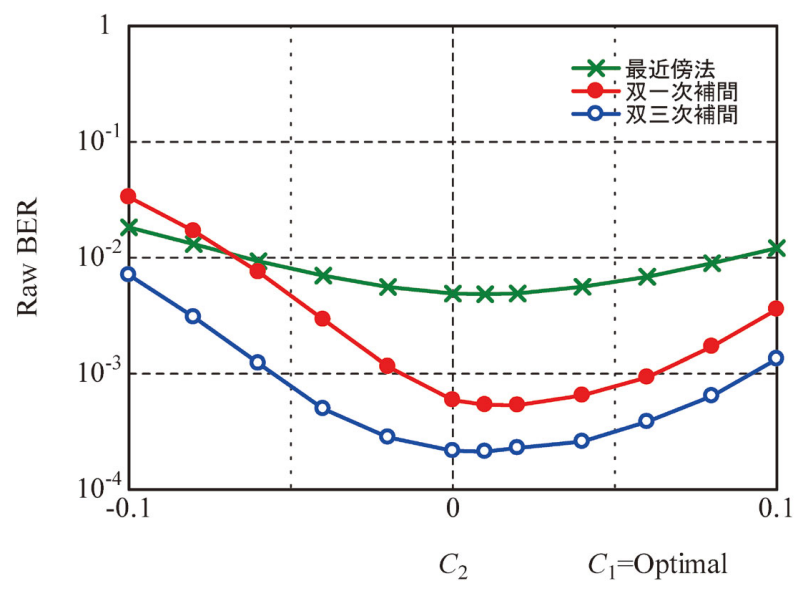

図10 各補間方法での $C_{2}$ に対するビット誤り率の変化 $(\alpha=-0.6$, 最近傍法, 双1次補間, 双 3 次補間においてそれぞれ $\left.C_{1}=-0.225,-0.26,-0.235\right)$

を最良值である $C_{1}=-0.235, C_{2}=0.01$ として式 (17) の $\alpha$ を 変化させた場合, 図11に示すと扔り誤り率は $\alpha$ の值に大き く依存しないことがわかる. 以上ょり, 補間とコンボ

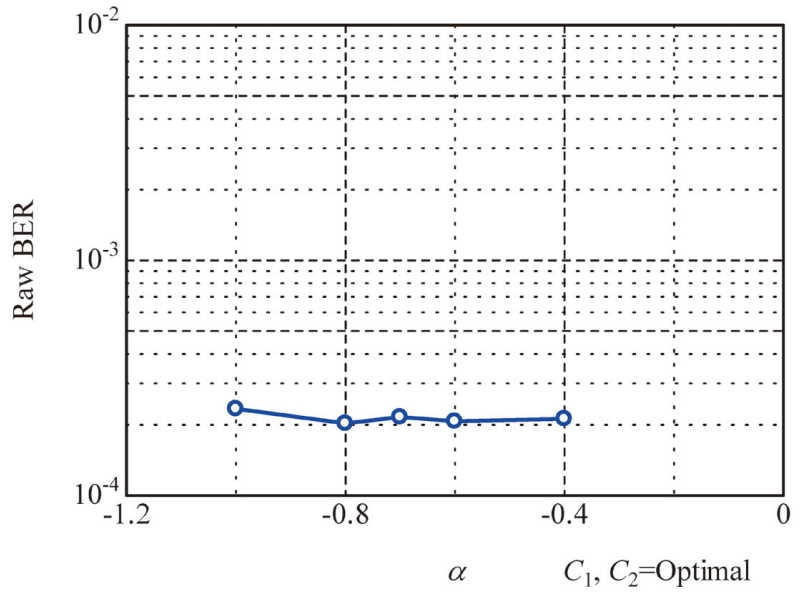

図11 双3次補間に扔ける $\alpha$ に対するビット誤り率の変化 $\left(C_{1}=-0.235, C_{2}=0.01\right)$

リューションフィルタの同時実装において，コンボリュー ションフィルタ係数を $C_{1}=-0.235, C_{2}=0.01$ に設定し, 補 間方法として $\alpha=-0.6$ の双 3 次補間を用いる場合に最も誤 り率が低くなる結果を得た。

\section{3 デインタリーブ}

図 12 にデインタリーブ操作の概念図を示す。まず8ペー ジデータを格納できるバッファをGPUのグローバルメモ リーとして確保し, 順次切出された再配列ページデータを バッファにバースト転送する。このとき，バッファのアド レス連続方向は図中の矢印方向とする，インタリーブ同様 に，デインタリーブは連続しないアドレスからデータをコ ピーし再配置する必要があるためバースト転送を使用でき ず，レイテンシーの累積により転送時間が増大する懸念が ある。そこで，この場合においても共有メモリーを経由す ることで高速化を図る.

まず， 8 ページ分のバッファを $40 \times 261$ のブロックに分 割し，一つのブロックで $32 \times 32$ のスレッドを実行させる. 一つのブロックはグローバルメモリーである8ページバッ ファの対象領域から共有メモリーへ96×96画素をコピー

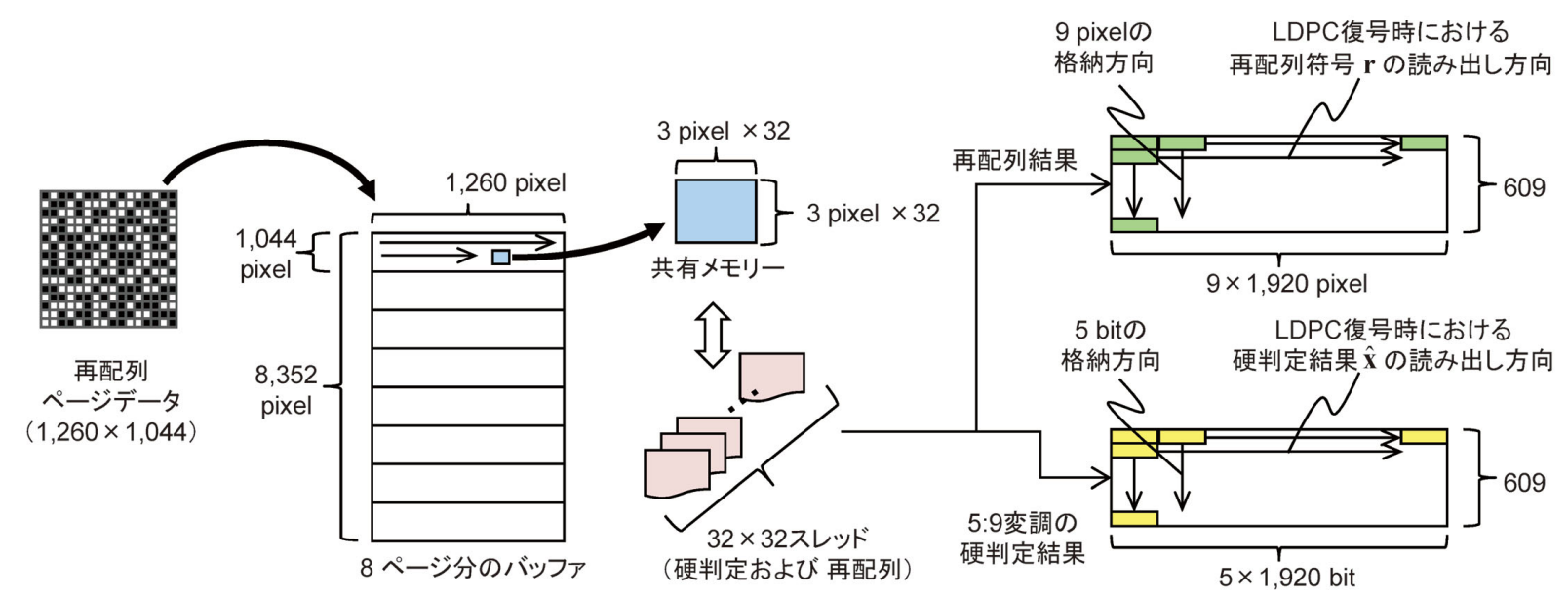

図12 デインタリーブの概念図 
し，各スレッドは $3 \times 3$ 画素について $5: 9$ 変調に基づく硬判 定と $9 \times 1$ 画素への再配列の後, グローバルメモリー上に 設けられたそれぞれのバッファへ格納する. 硬判定と再配 列の結果は後段の誤り訂正で用いる.

\section{4 誤り訂正}

訂正能力が高いLDPC符号の復号法として Sum-Product 法が知られている ${ }^{18)}$. そこで, ここではSum-Product法に 基づき, その対数尤度比の計算方法をホログラムメモリー の 5：9変調に対応するよう修正して復号を行う ${ }^{19)}$. 以下 に具体的な手順を示す.

$$
\text { ステップ1 }
$$

デインタリーブの段階で得られた再配列符号を $\mathbf{r}$ とし， 硬判定結果を復号語 $\hat{\mathbf{x}}$ の初期值とする.

\section{ステップ2}

検査行列 $\mathbf{H}$ における要素 $H_{m n}$ について,$H_{m n}=1$ を満たす $(m, n)$ に対し, 変数 $\beta_{m n}=0$ とする.

\section{ステップ3}

対数尤度比計算を行う. 推定したビット長 $N$ の復号語 $\hat{\mathbf{x}}$ に対して,$n$ 番目のビットを“ 1 ”よび“0”としたときの符 号語 $\mathbf{u}, \mathbf{v}$ を,

$$
\begin{aligned}
& \mathbf{u}=\Phi\left(\hat{x}_{1}, \hat{x}_{2}, \cdots \hat{x}_{n-1}, 1, \hat{x}_{n+1}, \cdots, \hat{x}_{N}\right) \\
& \mathbf{v}=\Phi\left(\hat{x}_{1}, \hat{x}_{2}, \cdots \hat{x}_{n-1}, 0, \hat{x}_{n+1}, \cdots, \hat{x}_{N}\right)
\end{aligned}
$$

とする。ここで $N=1,250, \hat{x}_{n}$ は復号語 $\hat{\mathbf{x}}$ の $n$ 番目の要素, $\Phi$ は符号語を $5 ： 9$ 変調することを示している，rと uおよ び $\mathbf{v}$ から, $n$ 番目における対数尤度比 $\hat{\lambda}_{n}$ を

$$
\hat{\lambda}_{n}=\ln \frac{\exp \left(-d^{2}(\mathbf{r}, \mathbf{u}) / N_{0}\right)}{\exp \left(-d^{2}(\mathbf{r}, \mathbf{v}) / N_{0}\right)}
$$

で求める.ここでdはユークリッド距離， $N_{0}$ はノイズ分散 を表す.

$$
\text { ステップ } 4
$$

行処理を行う. $H_{m n}=1$ を満たす $(m, n)$ に対し,

$$
\begin{aligned}
\gamma_{m n}= & \prod_{n^{\prime} \in A(m) \backslash n} \operatorname{sign}\left(\hat{\lambda}_{n^{\prime}}+\beta_{m n^{\prime}}\right) \\
& f\left(\sum_{n^{\prime} \in A(m) \backslash n} f\left(\left|\hat{\lambda}_{n^{\prime}}+\beta_{m n^{\prime}}\right|\right)\right)
\end{aligned}
$$

を計算する。ここで，

$$
\operatorname{sign}(a) \equiv\left\{\begin{array}{cc}
1 & (a \geq 0) \\
-1 & (a<0)
\end{array}\right.
$$

および

$$
f(a) \equiv \ln \frac{\exp (a)+1}{\exp (a)-1}
$$

であり, $A(m)$ は変数ノードのインデックス集合を表す.
ステップ5

列処理を行う. $H_{m n}=1$ を満たす $(m, n)$ に対し,

$$
\beta_{m n}=\sum_{m^{\prime} \in B(n) \backslash m} \gamma_{m^{\prime} n}
$$

を計算する。ここで， $B(n)$ はチェックノードのインデッ クス集合を示す.

ステップ6

推定した符号語

$$
\hat{x}_{n}=\left\{\begin{array}{l}
0, \quad \text { if } \operatorname{sign}\left(\hat{\lambda}_{n}+\sum_{m^{\prime} \in B(n)} \gamma_{m^{\prime} n}\right)=1 \\
1, \quad \text { if } \operatorname{sign}\left(\hat{\lambda}_{n}+\sum_{m^{\prime} \in B(n)} \gamma_{m^{\prime} n}\right)=-1
\end{array}\right.
$$

を計算する。

ステップ7

符号語の必要充分条件

$$
\hat{\mathbf{x}} \cdot \mathbf{H}^{\mathrm{T}}=\mathbf{o}
$$

を満たすならば，復号語 $\hat{\mathbf{x}}$ を出力してアルゴリズムを終了 する.

\section{ステップ 8}

繰り返し回数がその上限值より少ないとき，ステップ 3 に戻り演算を繰り返す。上限值に達した場合は復号を終了 する。

今回, LDPC 復号の GPU実装においてはテクスチャメモ リーを積極的に活用した.テクスチャメモリーは，グロー バルメモリーと同様に下層の大容量メモリーに位置づけら れるが，メモリー内容の定義後は読出し専用であること， テクスチャキャッシュと呼ばれる上層の高速なキャッシュ 機能を使用できる点が異なる。したがって，前述のLDPC

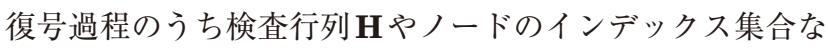
ど，規模が大きくかつ頻繁にアクセスされるが内容変更し ない配列をテクスチャメモリーに配置した。さらに，指数 関数の計算負荷が高いことから, 式 (23) の関数 $f(\alpha)$ をテ クスチャメモリー内であらかじめテーブル化することによ り高速化を図った.

\section{GPUによる再生信号処理実験}

\section{1 各処理段の時間測定}

前章で述べた各処理段および再生像取得, 転送に要する 時間を測定した。1ページデータあたりの時間測定結果を 表 1 に示す. なお, 8ページ単位で処理を行うデインタ リーブと誤り訂正については，8ページ処理後の 1 ページ データあたりの平均時間を示す。

イメージセンサの露光時間は, ホログラムの回折効率や 再生時の参照光パワーに依存する.強いホログラムを記録 し回折効率を高めた場合, 短い露光時間で充分な再生光量 を得られるが，記録媒体の光重合性高分子が有限であるた 
表1 各処理段の時間測定結果

\begin{tabular}{lc}
\hline \multicolumn{1}{c}{ 処理内容 } & $\begin{array}{c}\text { 時間 } \\
\text { (ms / page) }\end{array}$ \\
\hline イメージセンサの再生像取得（露光） & 2.0 \\
データ転送（イメージセンサーDRAM） & 4.2 \\
データ転送（DRAMーグローバルメモリー) & 0.6 \\
データ領域特定 & 0.3 \\
シンボル抽出 & 3.8 \\
デインターリーブ & 1.8 \\
誤り訂正 (LDPC符号の復号) & 4.7 \\
\hline
\end{tabular}

め角度多重数が低下する．また，高い出射パワーを有する レーザ光源を用いれば参照光パワーを増すことができる が，光源自体が大型になる課題がある．今回は記録媒体の 特性を踏まえた結果，最適な露光時間は $2.0 \mathrm{~ms}$ であった。

イメージセンサから DRAMへの転送時間は主に CameraLink インタフェースの帯域幅で律速される.さら に高速なインタフェースの使用により転送時間を短縮でき る可能性がある。一方, DRAMから GPUのグローバルメ モリーへの転送は, 計算器内部バス上のバースト転送であ るため $0.6 \mathrm{~ms}$ と比較的高速であった。

デー夕領域特定は, あらかじめ定義されたマーカ位置周 辺のみブロックマッチングを行うため, 短時間で処理を完 了した。

表 1 のシンボル抽出は，3.2節で最良な結果を示した双 3 次補間とコンボリューションフィルタの同時実装に拄ける 測定結果である。なお, 最近傍法とコンボリューション フィルタを同時実装した場合は $1.2 \mathrm{~ms}$ であった. 双 3 次補 間は最近傍法に比べ演算量が多いものの, ビット誤り率の 観点から有利である. シンボル抽出結果が後段のLDPC 復 号時間を増大させる懸念もあるため, 双 3 次補間とコンボ リューションフィルタの同時実装が現実的であると考えら れる.

デインタリーブは単純なシンボル並び替えだけでなく, 後段のLDPC 復号のために硬判定を行っていること, また シンボル抽出処理と同一の GPUを用いていること, などが 処理時間に影響していると考えられるが，1ページデータ
あたりの処理時間はボトルネックにならない測定結果で あった。一方, LDPC符号の復号は他の処理段と比較して 長い処理時間を要する.1符号あたりの平均繰り返し回数 が多くなるほど，その処理時間が増加するため，訂正前の ビット誤り率を低く抑えることが重要となる，表1に示し た測定結果は，再生ページデータの Raw BER平均值が揖 よそ $2 \times 10^{-3}$ の場合であり, 1 符号あたりの平均繰り返し 回数は 2.33 回であった。 それ以下の誤り率であれば 1 ペー ジデータあたりの LDPC 復号時間が $4.7 \mathrm{~ms}$ 以下になること が期待できる.

\section{2 パイプライン化}

一つの再生像が最終段の誤り訂正処理を完了する前に次 の再生像を受け入れるパイプライン化により，スループッ 卜向上を図った。パイプライン化した再生信号処理の遷移 図を図13に示す。

イメージセンサの再生像取得（露光）とDRAMへのデー 夕転送が完了した段階で, イメージセンサは次の再生像取 得命令(トリガ) を受け付ける. 次の再生像を取得する間に, DRAMから GPUのグローバルメモリーへ再生像を転送す る. その後, GPUはデー夕領域特定とシンボル抽出を順次 行い，その間に次の再生像がイメージセンサから DRAM へ転送される。

再生ページデータが8枚分蓄積された段階で, デインタ リーブ，䛊り訂正を順次行うが，その間にも再生像取得か らシンボル抽出までを並行して実行する．図13のとおりパ イプライン処理を動作させるよう，CPUが同期制御した。

表1の時間測定結果と図13に示したパイプライン処理の 遷移図を考虑すれば，ホログラムを連続再生するうえで1 ページデータあたりの所要時間はイメージセンサ露光時間 $(2.0 \mathrm{~ms})$ とDRAMへの転送時間 $(4.2 \mathrm{~ms})$ の和 $(6.2 \mathrm{~ms})$ によ り決定されることがわかる. 䛊り訂正符号を含めた 1 ペー ジデータあたりの情報量は,

$$
N_{x} \cdot N_{y} \cdot \frac{5}{9}=730,800 \mathrm{bit}
$$

であるから，1ページデータあたりの所要時間を用いて

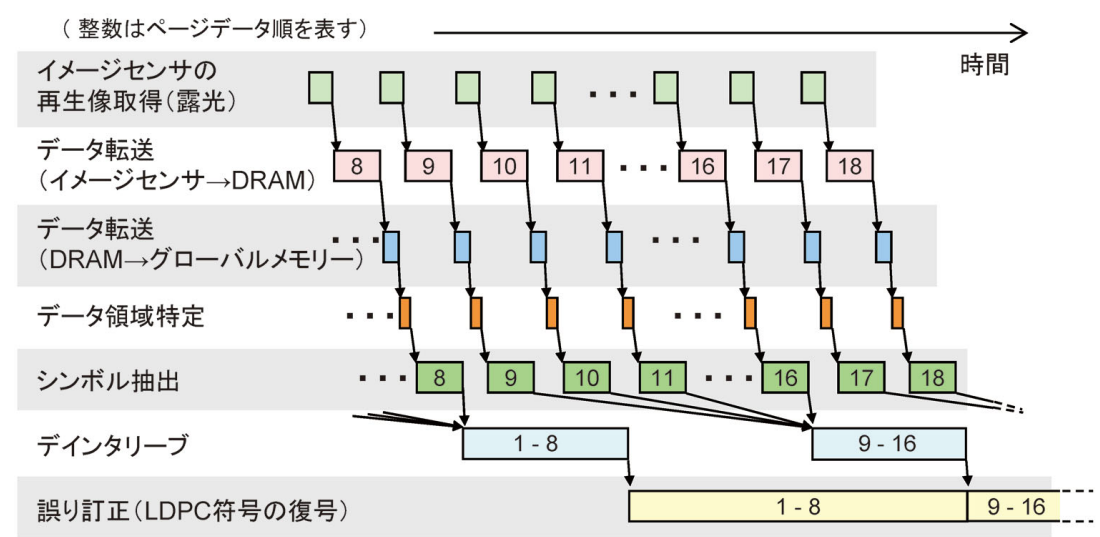

図13 パイプライン化した再生信号処理の遷移図 


\section{$730,800 / 0.0062=118 \mathrm{Mbps}$}

の総レートを得る。また，符号化率 0.812 を考慮すると ユーザレートとして

$$
730,800 / 0.0062 \times 0.812=95.7 \mathrm{Mbps}
$$

を得る。

以上より，ホログラムメモリーの再生信号処理系におい て，GPUに特化した再生信号処理アルゴリズムをパイプラ イン化して実装した結果，95 Mbps 以上のスループットが 確認できた。

\section{3 高精細映像の再生実験}

GPUに実装した再生信号処理系の総合評価を行うため, 15 秒の高精細映像（解像度 $1,920 \times 1,080)$ をページデータ化 してホログラムメモリーに記録後, 再生した. 得られた再 生ページデータをGPU再生信号処理系により処理し, 元の 映像が正常に復元されることを確認した ${ }^{20)}$. 用いた映像 コーデックはMPEG-4 AVC/H.264，ビットレートとフ レームレートはそれぞれ $15 \mathrm{Mbps} ， 30 \mathrm{fps}$ である.

映像デー夕量は 28 MByteであり，2.2節で述べたページ デー夕構成法に基づき 378 枚のページデー夕を生成した。 今回は記録媒体の1箇所あたりの角度多重数を 96 に設定し た.したがって，378枚のページデータの末尾に6枚のダ ミーデータを追加し合計 384 枚とした後, 記録媒体の 4 箇 所（ピッチ $1 \mathrm{~mm}$ ) に96枚ずつ角度多重した。

次に, イメージセンサ露光時間を $2.0 \mathrm{~ms}$ としてホログラ ムを連続再生した。再生された 384 枚のページデータに対 するRaw BERを図14に示す。このときのRaw BERの平 均值は $1.55 \times 10^{-3}$ であった。第 3 章で一つだけホログラム を記録再生し得られたRaw BER と比較すると，ビット誤 りが増加している。 これは, 角度的に隣接するページデー 夕間のクロストークが要因と考えられるが6), 誤り訂正後 に得られた映像デー夕を元データと比較し，すべてのビッ 卜䛊りが訂正されていることを確認できたことから，どの 再生ページデータも訂正可能な誤り率を示したと言える.

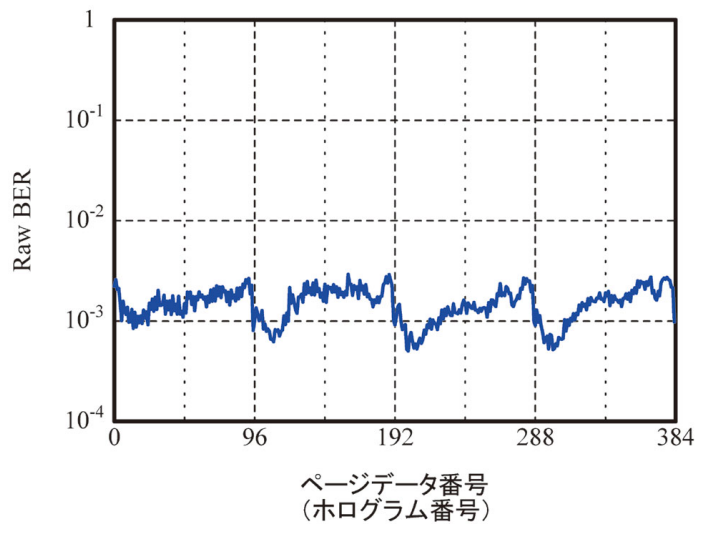

図14 全ページデータに対するRaw BER 測定結果
記録媒体の4箇所から全ホログラムを再生するために要 した時間は $8 \mathrm{~s}$ であった。記録媒体の 1 箇所からの再生時間 は $0.6 \mathrm{~s}$ 程度で完了するが，記録媒体の位置移動と，移動後 の記録媒体の振動停止に時間を要した。今後，機構系の改 良によりスループットを最大限に引き出すことができると 考える。

\section{5.むすび}

ホログラムメモリーはページデータと呼ばれる 2 次元 デー夕配列を一括して記録または再生するため，従来の光 デイスクに比べ高いデー夕転送速度が期待できる．本論文 では，ホログラムメモリーから再生されるページデータが 一種の画像と見なせることに着目し，グラフィクス処理に 特化したGPUによる再生信号処理アルゴリズムを新規に開 発し，これを評価した。

各処理段における時間を測定するとともに，各処理段を パイプライン化することにより，GPUによる再生信号処理 系として $95 \mathrm{Mbps}$ 以上のスループットを確認した。次いで， 高精細映像から 384 枚のページデータを生成し，これらを ホログラムとして記録，再生した結果，すべてのビット誤 りが訂正され，映像再生されることを確認した。

今後, GPUの並列数を増加させるとともに，それに対応 した各アルゴリズムの改良を進めることで，更なるスルー プットの改善が見込まれる。また，本論文では再生信号処 理に焦点を当てたが，今後は記録時のページデー夕生成に も GPU処理の適用を進める.

GPUは信号処理アルゴリズム構成やパラメータの変更が 容易であるため，光学系の構成変更に応じた迅速なアルゴ リズム検証が可能である。これは，ホログラムメモリーに おいて光学系と信号処理アルゴリズムの双方を同時に開発 するうえでの大きな利点である。ささらに，GPUにより得ら れたアルゴリズム検証結果を FPGA (Field-Programmable Gate Array) や ASIC (Application Specific Integrated Circuit) などの集積回路設計へ反映させることで，より実用的なホ ログラムメモリーシステムの早期実現が期待される.

本研究を進めるにあたり，新日鉄住金化学株式会社様よ り記録媒体サンプルをご提供いただきました。ここに深く 謝意を表します。

\section{〔文 献〕}

1) L. Hesselink, S.S. Orlov and M.C. Bashaw: "Holographic data storage systems", Proc. IEEE, 92, 8, pp.1231-1280 (Aug. 2004)

2) J. Ashley, M.-P. Bernal, G.W. Burr, H. Coufal, H. Guenther, J.A. Hoffnagle, C.M. Jefferson, B. Marcus, R.M. Macfarlane, R.M. Shelby and G.T. Sincerbox: "Holographic data storage", IBM J. Res. Develop. 44, 3, pp.341-368 (May 2000)

3) N. Ishii, T. Muroi, N. Kinoshita, H. Kikuchi, K. Kamijo and N. Shimidzu: "Holographic Data Storage System toward High Recording Density", presented at Photonics West 2011, 7957-25 (Jan. 2011)

4）室井：“ホログラフィックメモリー”，映情学誌， $68,1, p p .42-45$ (Jan. 2014) 
5) M. Hosaka, T. Ishii, A. Tanaka, S. Koga and T. Hoshizawa: "1 Tbit/inch ${ }^{2}$ Recording in Angular-Multiplexing Holographic Memory with Constant Signal-to-Scatter Ratio Schedule", Jpn.J. Appl. Phys., 52, 9, pp.09 LD01.1-09 LD01.5 (Sep. 2013)

6) N. Kinoshita, T. Muroi, N. Ishii, K. Kamijo and N. Shimidzu: "Control of Angular Intervals for Angle-Multiplexed Holographic Memory", Jpn.J. Appl. Phys., 48, 3, pp.03 A029.1-03 A029.4 (Mar. 2009)

7) T. Ando, T. Shimizu and K. Masaki: "Multiplexing Characteristics of Aromatic Photopolymer for Holographic Data Storage Media", Int'l Workshop on Holography and related technologies (IWH) 2011 Digest, P16, pp.53-54 (Nov. 2011)

8）須田：“GPU と GPGPUの概要”, 映情学誌, 66, 10, pp.808-812 (Oct. 2012)

9）冨山, 岩舘：“多視点ハイビジョン映像生成システムの開発”, 映情 学誌, 64, 4, pp.622-628 (Apr. 2010)

10) 浜田，高橋，苗村： “超解像自由視点画像合成の高速化実装”, 映情 学誌, 66, 10, J385-J394 (Oct. 2012)

11) 藤澤, 加藤：“GPUを用いたインタラクティブフォトモザイク”, 映 情学誌，64，9,pp.1382-1384（Sep. 2010）

12)杉藤：“CUDA プログラミング”, 映情学誌, 66, 10, pp.813-816 (Oct. 2012)

13) H. Pishro-Nik, N. Rahnavard, J. Ha, F. Fekri and A. Adibi: "LowDensity Parity-Check Codes for Volume Holographic Memory System", App. Opt., 42, 5, pp.861-870 (Feb. 2003)

14)木下, 石井, 室井, 上條, 清水：“ホログラフィックメモリー用変調 テーブルの一構成法”，映情学年大，8-4（Aug. 2007）

15) 本山, 杉山, 原田, 山本：“ディジタルホログラム情報の高速・高精 度デー夕位置検出処理”，信学技報，103，494, pp.7-12（Dec. 2003）

16) N. Kinoshita, T. Muroi, K. Kamijo and H. Kikuchi: "Precise Symbol Extraction in Holographic Data Storage", Tech. Dig. of Int'l. Symp. Opt. Mem. (ISOM), Mo-C-02, p.34-35 (Aug. 2013)

17) 特許第4809756 号公報

18) 仲村, 柳田, 大沢, 岡本, 村岡 : “LDPC符号化・繰り返し復号化方 式における誤り伝搬抑制の一検討”，映情学技報，37，26, pp.13-17 (June 2013)

19)室井, 石井，木下，上條，菊池：“ホログラム記録におけるLDPC符 号化 5:9 変調方式の復号と HD 映像再生”, 映情学技報, 36, 55, pp.912 (Dec. 2012)

20) N. Kinoshita, N. Ishii, T. Muroi, K. Kamijo, T. Ando, K. Masaki, T. Shimizu and H. Kikuchi: "HDTV Playback Demonstration of Holographic Data Storage System using Wavefront Control \& GPUBased Post-Processing", Tech. Dig. of Int'l. Symp. Opt. Mem. (ISOM), Th-N-01, pp.210-211 (Oct. 2012)

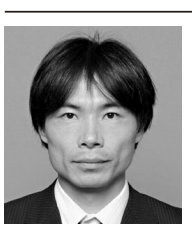

势告态延博 1997 年, 同志社大学大学院工学研究科 博士前期課程修了. 同年, NHK入局. 大阪放送局を経て, 2000 年より，放送技術研究所にて，主に，光ディスク， ホログラムメモリーの研究に従事. 博士 (工学)。正会員.

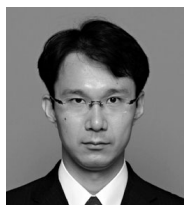

室并哲彦 2002 年, 電気通信大学大学院電気通信 学研究科博士後期課程修了. 同年, NHK 放送技術研究所 Post Doctoral Fellow. 2004年，NHK入局. 放送技術研 究所に勤務. 冷㓌極デイスプレイ，ホログラムメモリー の研究に従事. 博士 (工学). 正会員.

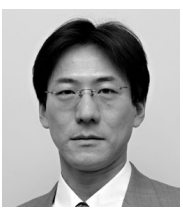

石井 紀彦 1993年, 慶應義塾大学大学院理工学研 究科修士課程修了. 同年, NHK 入局. 放送技術研究所以 て，主に，光通信用デバイス，光メモリー材料，扔よび ホログラムメモリーの研究に従事. 博士 (工学). 正会員.

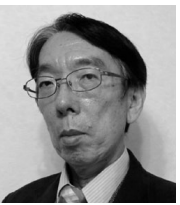

上條掌司 1978 年, 電気通信大学電気通信学部応 用電子工学科卒業。同年，NHK入局．1981年より，同放 送技術研究所に勤務し，現在に至る。超広帯域磁気記録， ハイビジョンVTR，光記録，ホログラムメモリーの研究 に従事. 正会員.

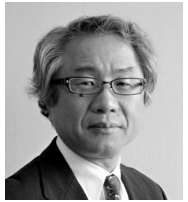

菊池喜 1984 年, 豊橋技術科学大学大学院工学 研究科修士課程修了. 同年, NHK 入局. 神戸放送局を経 て，1987年より，同放送技術研究所. 2008年～2010年, (独) 情報通信研究機構に出向. 液晶・磁気光学材料を用 いた空間光変調器, 3 次元カメラ, ホログラム記録・表示 などの研究に従事. 博士 (工学)，正会員.

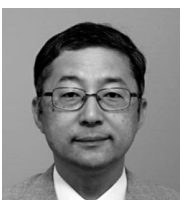

清水直樹 1982 年, 早稲田大学大学院理工学研究 科修士課程修了. 同年, NHK入局. 放送技術研究所にて, 光記録，表示デバイスの研究・開発に従事. 博士 (工学). 正会員。 